FULL RESEARCH ARTICLE

\title{
Home range and movements of San Joaquin antelope squirrels in the San Joaquin Desert of California
}

\author{
DAVID J. GERMANO ${ }^{1 *}$, GALEN B. RATHBUN ${ }^{2}{ }^{2}$, LAWRENCE R. SASLAW ${ }^{3}$, AND \\ BRIAN L. CYPHER ${ }^{3}$
}

${ }^{1}$ Department of Biology, California State University, Bakersfield, CA 93311, USA

${ }^{2}$ Institute of Biodiversity Science and Sustainability, California Academy of Sciences, San Francisco, CA 94118, USA

${ }^{3}$ Endangered Species Recovery Program, California State University-Stanislaus, One University Circle, Turlock, CA 95382, USA

*Corresponding Author: dgermano@csub.edu

+Deceased

The San Joaquin antelope squirrel (Ammospermophilus nelsoni) is one of five species in the genus and has the most restricted range of the four mainland antelope squirrels, occurring only in the San Joaquin Desert of California. Despite being state-listed as Threatened since 1980, few studies have been conducted on $A$. nelsoni, especially ecological studies, which hampers recovery efforts. We conducted a radio-telemetry study in 2002 of 19 males on the Lokern Natural Area in the southwestern portion of the San Joaquin Desert. Based on 100\% Minimum Convex Polygons (MCP), home ranges varied from $1.25-14.5$ ha with a mean of 5.93 ha ( \pm 0.90 standard error). The average daily distance traveled by these 19 males was $128.5 \mathrm{~m}$ (range, 71.4-224.5) and the average greatest distance travelled in a day was $313.0 \mathrm{~m}$, with some traveling $>0.5 \mathrm{~km}$. Our data are useful to further refine the estimates of home range and movements of this neglected protected species, but in the future, better home range studies are needed that span multiple years, include both sexes, and occur at sites across its range.

Key words: Ammospermophilus nelsoni, conservation, home range, Minimum Convex Polygons, movements, radio telemetry, San Joaquin antelope squirrel

The San Joaquin antelope squirrel (Ammospermophilus nelsoni) is one of five species of antelope squirrels (Ammospermophilus) that occur only in the deserts of North America (Mantooth et al. 2013). Ammospermophilus nelsoni has the most restricted range of a non- 
island antelope squirrel (Mantooth et al. 2013), occurring only in the San Joaquin Desert of California (Grinnell and Dixon 1918; Harris 1998; Germano et al. 2011). All antelope squirrels are small sciurids, weighing from 99 to $179 \mathrm{~g}$ (Kays and Wilson 2002), and have multiple adaptations for desert life (Eisenberg 1975; Ghobrial and Nour 1975; Chappell and Bartholomew 1981; Walsberg 2000). In particular, A. nelsoni exhibits a variety of adaptations, including (1) light colored pelage, (2) relatively large auditory bullae to compensate for low sound transmission in deserts (but see Mason 2016), (3) soles of the feet that are heavily furred, (4) sparse summer pelage and denser, darker winter pelage, (5) ability to behaviorally dump body heat to cool soil in the shade or in a burrow, and (6) a hypothalamus sensitive to body temperature that will decrease metabolic heat production when $>40^{\circ} \mathrm{C}$ (Heller and Henderson 1976; Best et al. 1990).

In the San Joaquin Desert, $A$. nelsoni occurs with several other protected species (USFWS 1998; Germano et al. 2001), and was state listed as Threatened in 1980 because much of the natural lands in this region have been converted to agricultural, urban, and industrial uses (USFWS 1998). It once was widely distributed in arid shrubland and grassland habitats in the western and southern portions of the San Joaquin Valley from western Merced County south to Kern County and also on the Carrizo Plain (Fig. 1). Despite its protected status, few studies of the ecology of this species have been made, and even fewer have been published. In 1997 we began studying the effect that grazing by cattle has on populations of $A$. nelsoni and other protected species in the San Joaquin Desert (Germano et al. 2012). We censused $A$. nelsoni using trapping grids on the Lokern Natural Area study area beginning in 1997. We found that numbers of A. nelsoni were significantly higher on plots grazed by cattle during the 10 -y study (Germano et al. 2012). Here we report the results of another study conducted in 2002 in which we radio-tracked A. nelsoni caught on grids to determine home ranges of the squirrels and if there were any differences in the sizes of home ranges on grazed and control areas of the study site. Estimates of home range size are also important metrics for understanding how development can affect species and can lead to better conservation and recovery actions for a species.

\section{METHODS}

\section{Study Area}

We studied A. nelsoni at the Lokern Natural Area (Fig. 1), which is in the southwestern end of the San Joaquin Desert (Germano et al. 2011), about $50 \mathrm{~km}$ west of Bakersfield in Kern County, California. The site $\left(35^{\circ} 22^{\prime} 24^{\prime \prime} \mathrm{N} 119^{\circ} 36^{\prime} 33^{\prime \prime} \mathrm{W}, 158 \mathrm{~m}\right.$ elevation) is a large and broad alluvial fan that is relatively undisturbed at the base of the Elk Hills, although the natural area is bordered by intensive agriculture, oil fields, and a large hazardous waste disposal site. The site is dominated by saltbush (Atriplex spp.), non-native annual grasses, and native annual forbs (Germano et al. 2012). Because the natural area is large $(5,285 \mathrm{ha})$, relatively undisturbed, and mostly protected, other ecological studies have been performed there (Cypher et al. 2009; Germano et al. 2012; Germano and Rathbun 2016).

\section{Data Collection}

We radio-tracked A. nelsoni in August and September 2002. We used Holohil Systems (Carp, Ontario, Canada) model MD-2C transmitters (4.0 g; $164 \mathrm{MHz})$ on the squirrels, 


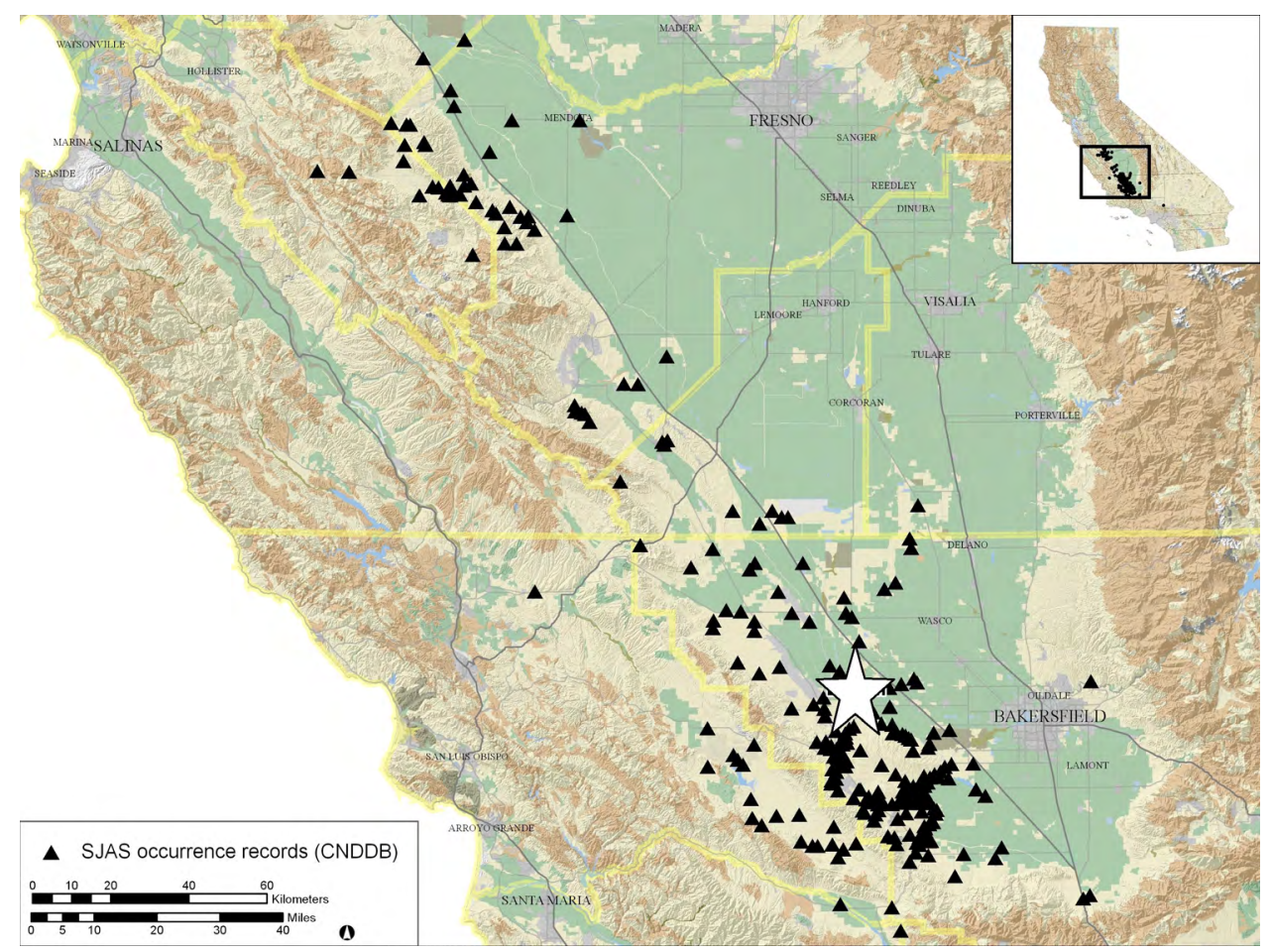

Figure 1. Occurrence records (black triangles) of the San Joaquin antelope squirrel (Ammospermophilus nelsoni) in the San Joaquin Desert of California. The approximate location of the Lokern Study Site (white star) is where we conducted a radio-telemetry study in 2002 on 19 male squirrels.

which we attached using wire and Tygon tubing collars (Holohil Systems). We recorded locations for squirrels on foot using a Communications Specialists (Orange, CA, USA) receiver (model R1000) and an H-Adcock or three-element Yagi receiving antenna and determined the UTM (Universal Transverse Mercator) coordinates of all loci with a GPS receiver (GeoExplorer 3; Trimble, Sunnyvale, CA, USA) with differential and real-time correction. With this unit, we measured $\mathrm{a} \pm 2$ - $\mathrm{m}$ variation $(\mathrm{n}=7)$ for a single location during the period of our radio tracking.

We attached radio-collars to 20 male antelope squirrels at the end of July 2002. To increase sample size because of limited numbers of transmitters, we only radio-tagged males to eliminate the confounding effect of the sex of the animals. Although we intended to only tag adults $(\geq 130 \mathrm{~g}$ in weight), we found it necessary to tag five subadults $(106-129 \mathrm{~g})$ and four juveniles $(\leq 105 \mathrm{~g})$ to achieve a sample of 20 . Transmitters weighed $2.5-4.3 \%$ of the body mass of squirrels. Of the four square-mile sections $\left(10.36 \mathrm{~km}^{2}\right)$ on our study site (21, 27, 29, and 33), we did not tag animals on Section 27 because the high density of kangaroo rats in this area had resulted in minimal difference in residual dry matter between treatment (grazed) and control pastures. We, therefore, only collared animals on Sections 21, 29, and 33 (Fig. 2). We recaptured all radio-tagged squirrels and removed their collars 16-24 September 2002. 
We attempted to radio-locate each antelope squirrel twice per day (except weekends), once in the morning and once in the afternoon. We tried to ensure that at least $4 \mathrm{~h}$ separated the two daily locations to eliminate auto-correlation between loci. We also haphazardly changed the order in which we located individuals to eliminate any temporal biases in locations. The diurnal antelope squirrels do not use a home burrow; meaning that each night they usually switch to a different burrow. The total number of night burrows is usually between five and 10 (G.B. Rathbun, unpublished data). During the day, A. nelsoni range widely over their home ranges and use many burrows as temporary refuges from disturbances, such as the biologists who radio-track them. Thus, we determined all our locations by homing in on animals in burrows rather than by triangulation (Kenward 2001).

\section{Home Range and Distance Analyses}

We calculated home range size of $A$. nelsoni using the Minimum Convex Polygon (MCP) technique (Home Range Extension in ArcView 3.2; Esri, Redlands, CA, USA). We calculated home range size based on both $100 \%$ and $50 \%$ (core area) MCP. We collected data on 19 squirrels (one radio was lost within a few days), 12 of which were in plots grazed by cattle in earlier years (Germano et al. 2012) and seven of which were in non-grazed

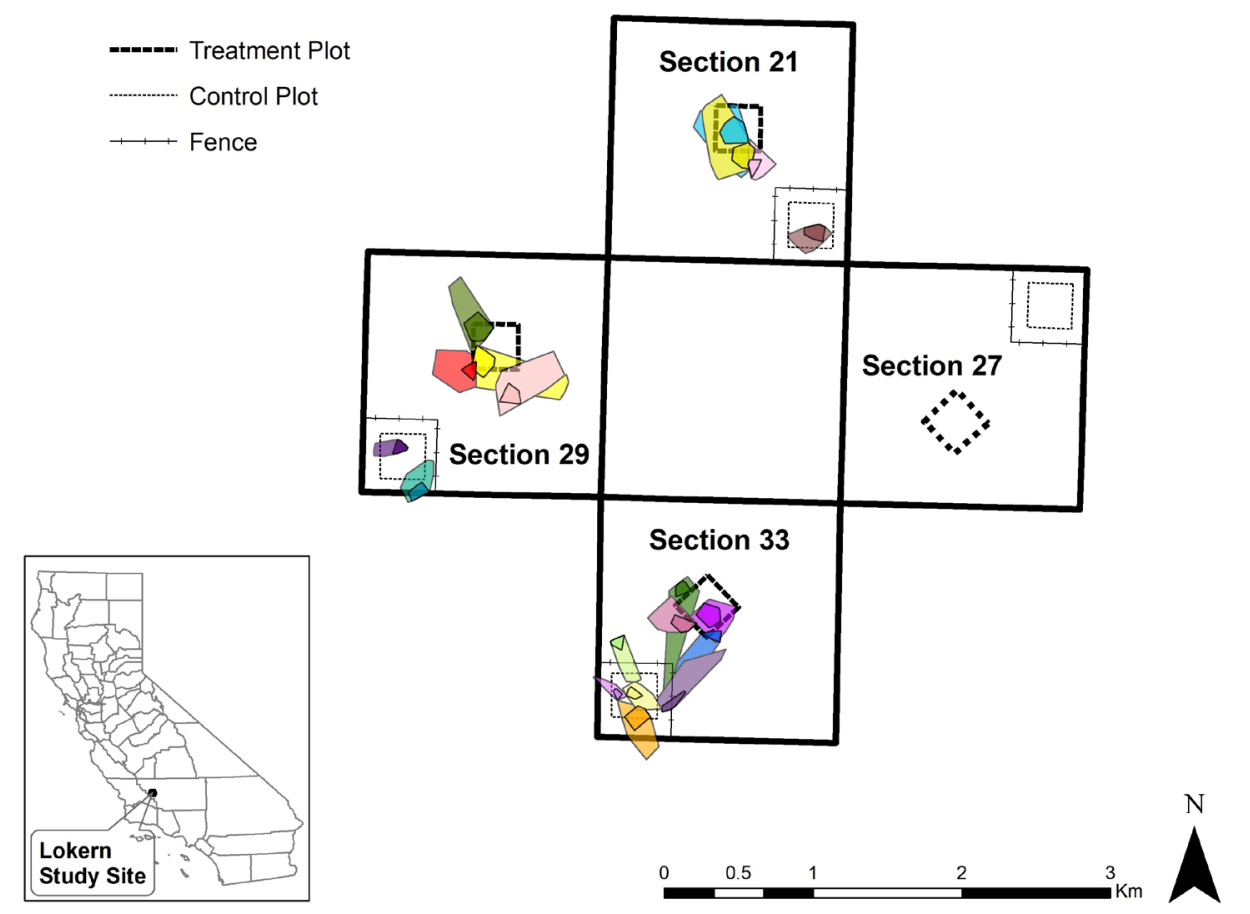

Figure 2. Home ranges of San Joaquin antelope squirrel (Ammospermophilus nelsoni) based on 100\% Minimum Convex Polygons (MCP; outer polygons) and 50\% MCP (darker inner polygons) in treatment (grazed) and control (ungrazed) plots in 2002 at the Lokern study site in the southern San Joaquin Desert of California, USA. Numbers 21, 27, 29, and 33 are treatment pastures (Sections), small, imbedded squares in the corners of sections are control pastures ( $500 \mathrm{~m}$ on a side), and squares with dashed outlines are treatment and control plots. 
plots. We collected between 17 and 48 locations for each squirrel (mean $=34.4$, standard error $=2.35$; Table 1). Data for 50\% MCP home range sizes met parametric assumptions, and after square root transformation for $100 \% \mathrm{MCP}$, data of home range sizes were normal and homoscedastic. We compared home range sizes of untransformed data of $50 \% \mathrm{MCP}$ and transformations of $100 \% \mathrm{MCP}$ between control and treatment plots using One-Way ANOVA with $\alpha=0.05$. We also compared $100 \%$ MCP and 50\% MCP by age classes (adult, sub-adult, and juveniles) using the Kruskal-Wallis test $(\alpha=0.05)$.

To determine distances that $A$. nelsoni moved between consecutive daily radio locations (ignoring distances from locations taken $>1 \mathrm{~d}$ apart), we used the ArcView Path With Distance and Bearing Extension, v. 3.2b. Data for average and greatest distance moved daily between treatment and control plots were normal and homoscedastic. We compared average and greatest distances moved between plot types with One-Way ANOVA $(\alpha=0.05)$. We compared average and greatest distances moved by age classes using the Kruskal-Wallis test $(\alpha=0.05)$.

Table 1. Identification number (ID), weight ( $\mathrm{g}$ ), age class ( $\mathrm{A}=$ adult, $\mathrm{S}=$ sub-adult, $\mathrm{J}=$ juvenile), the number of radio-telemetry locations (No. Points), 100\% and 50\% Minimum Convex Polygon (MCP) home range sizes (ha), and average movement distances (AMD, in m) of male San Joaquin antelope squirrel (Ammospermophilus nelsoni) at the Lokern study site in the southern San Joaquin Desert of California, USA, in 2002.

\begin{tabular}{cccccccc}
\hline ID & $\begin{array}{c}\text { Weight } \\
(\mathrm{g})\end{array}$ & $\begin{array}{c}\text { Age } \\
\text { Class }\end{array}$ & $\begin{array}{c}\text { Sec/ } \\
\text { Treat }\end{array}$ & $\begin{array}{c}\text { No } \\
\text { Points. }\end{array}$ & $\begin{array}{c}100 \% \\
\text { MCP }\end{array}$ & $\begin{array}{c}50 \% \\
\text { MCP }\end{array}$ & $\begin{array}{c}\text { AMD } \\
(\mathrm{m})\end{array}$ \\
\hline 1 & 142 & A & $33 \mathrm{~T}$ & 46 & 4.438 & 0.594 & 114.1 \\
2 & 140 & A & $33 \mathrm{~T}$ & 47 & 2.363 & 0.665 & 72.7 \\
3 & 153 & A & $33 \mathrm{~T}$ & 45 & 5.206 & 1.730 & 114.1 \\
4 & 159 & A & $33 \mathrm{~T}$ & 17 & 4.641 & 1.101 & 89.3 \\
5 & 98 & J & $29 \mathrm{~T}$ & 42 & 14.48 & 2.056 & 224.5 \\
6 & 111 & S & $29 \mathrm{~T}$ & 45 & 7.128 & 2.397 & 152.7 \\
7 & 95 & J & $29 \mathrm{~T}$ & 48 & 6.530 & 0.667 & 135.3 \\
8 & 111 & S & $21 \mathrm{~T}$ & 45 & 12.09 & 2.509 & 140.7 \\
9 & 153 & A & $21 \mathrm{~T}$ & 42 & 12.69 & 1.963 & 131.4 \\
10 & 103 & $\mathrm{~J}$ & $21 \mathrm{~T}$ & 21 & 2.808 & 0.590 & 75.7 \\
11 & 143 & A & $29 \mathrm{~T}$ & 19 & 10.74 & 1.218 & 156.0 \\
12 & 112 & S & $21 \mathrm{C}$ & 32 & 3.378 & 1.128 & 85.4 \\
13 & 139 & A & $33 \mathrm{C}$ & 28 & 5.901 & 1.529 & 174.4 \\
14 & 134 & A & $33 \mathrm{C}$ & 26 & 1.245 & 0.235 & 71.4 \\
15 & 122 & S & $33 \mathrm{~T}$ & 29 & 7.097 & 0.754 & 222.1 \\
17 & 105 & S & $29 \mathrm{C}$ & 34 & 1.845 & 0.559 & 104.8 \\
18 & 153 & A & $33 \mathrm{C}$ & 28 & 2.888 & 0.490 & 130.6 \\
19 & 139 & A & $33 \mathrm{C}$ & 27 & 3.262 & 0.506 & 135.8 \\
20 & 158 & A & $29 \mathrm{C}$ & 33 & 4.024 & 0.916 & 110.6 \\
\hline & & & & & & &
\end{tabular}




\section{Between-Trap Distance Analysis}

Using data collected in August 2002 during trapping at eight plots (four control, four treatment) for a grazing study on the Lokern (Germano et al. 2012), we calculated daily squirrel movements as the distances between trap locations on the X, Y stations of the trap grid. Plots consisted of an $8 \times 8$ grid of 64 Tomahawk live traps with 40-m trap spacing. Trapping sessions lasted $6 \mathrm{~d}$. In instances where squirrels did not move vertically or horizontally along trap lines, we calculated the diagonal distances between traps based on the hypotenuse of a right triangle. We only used trap locations of individual animals caught on consecutive days to calculate movement distances. We assumed data were normal based on the Central Limit Theorem ( $\mathrm{n}>30$ for all groups) and we determined that data were homoscedastic. We used Two-way ANOVA $(\alpha=0.05)$ to compare distances moved daily between males and females, between control and treatment plots, and the interaction of these groups.

\section{RDM and Invertebrate Numbers}

We measured the residual dry matter (RDM) on each plot in which we radio-tracked squirrels (Germano et al. 2012). This was done in August during trapping sessions using 30 quarter- $\mathrm{m}^{2}$ quadrats placed randomly in the trapping grid. Although some RDM remained from the previous year, most of the RDM was due to herbaceous plant production for the current year, and we used this as a measure of current plant production. We also checked the 10 pit-fall traps arrayed along the edge of each plot each day during trapping (Germano et al. 2012). Pit-fall traps were 19.1 L plastic buckets that we had dug into the ground up to the edge of the bucket. Traps were open continuously during the $6 \mathrm{~d}$ of squirrel trapping. We averaged the number of invertebrates found in the traps as an estimate of arthropod abundance on each plot. We excluded the number of ants we found in invertebrate numbers as they are not typically food for A. nelsoni (Hawbecker 1947) and ant numbers were much higher than other invertebrates (Germano et al. 2012), which we suspected would skew our comparisons. For both RDM and invertebrate numbers, data were normal and homoscedastic. We compared separately the estimates of RDM and abundance of invertebrates between control and treatment plots using $\operatorname{ANOVA}(\alpha=0.05)$.

\section{RESULTS}

The home ranges of $A$. nelsoni on the Lokern in 2002 varied in size and were spread across the treatment and control plots that we used (Fig. 2). The mean home range sizes (Table 2 ) did not differ significantly among age classes (100\% MCP: $H=0.88$, df $=2, P=$ $0.643 ; 50 \% \mathrm{MCP}: H=1.32, \mathrm{df}=2, P=0.516)$. The average MCP home range size using $100 \%$ of loci for each individual was 3.48 ha on control plots and 7.38 ha on treatment plots (Table 2$)$, which were significantly different $\left(F_{1,17}=8.38, P=0.010\right)$. The average $50 \%$ MCP home range size was 0.77 ha on control plots and 1.35 ha on treatment plots (Table 2), but these differences were not significant $\left(F_{1,17}=3.61, P=0.075\right)$. Irrespective of plot type, mean home range size was 5.93 ha for $100 \% \mathrm{MCP}$ and 1.14 ha for $50 \% \mathrm{MCP}$ (Table 2).

The mean average and greatest distances moved (Table 3 ) did not differ significantly among age classes (Average: $H=0.83$, $\mathrm{df}=2, P=0.662$; Greatest: $H=1.24$, $\mathrm{df}=2, P=$ 0.538 ). The average distance moved daily by squirrels on treatment plots was $135.7 \mathrm{~m}$ and 
Table 2. Sample size (n), mean, standard error (SE), and range of $100 \%$ and $50 \%$ Minimum Convex Polygon (MCP) home range sizes (ha) of male San Joaquin antelope squirrel (Ammospermophilus nelsoni) by age class (adult, sub-adult, and juvenile) and by treatment (grazed) and control (ungrazed) plots in 2002 at the Lokern study site in the southern San Joaquin Desert of California, USA.

\begin{tabular}{|c|c|c|c|c|c|c|c|c|}
\hline \multirow{2}{*}{$\begin{array}{l}\text { Age Class/ } \\
\text { Plot Type }\end{array}$} & \multicolumn{4}{|c|}{$100 \% \mathrm{MCP}$} & \multicolumn{4}{|c|}{$50 \% \mathrm{MCP}$} \\
\hline & $\mathrm{n}$ & Mean & SE & Range & $\mathrm{n}$ & Mean & SE & Range \\
\hline Adults & 11 & 5.22 & 1.05 & $1.25-12.7$ & 11 & 1.00 & 0.17 & $0.24-1.96$ \\
\hline Sub-adults & 5 & 6.31 & 1.78 & $1.85-12.1$ & 5 & 1.47 & 0.41 & $0.56-2.51$ \\
\hline Juveniles & 3 & 7.94 & 3.44 & $2.81-14.5$ & 3 & 1.10 & 0.48 & $0.59-2.06$ \\
\hline Treatment & 12 & 7.52 & 1.17 & $2.36-14.5$ & 12 & 1.35 & 0.21 & $0.59-2.51$ \\
\hline Control & 7 & 3.22 & 0.57 & $1.25-5.90$ & 7 & 0.77 & 0.17 & $0.24-1.53$ \\
\hline Combined & 19 & 5.93 & 0.90 & $1.25-14.5$ & 19 & 1.14 & 0.16 & $0.24-2.51$ \\
\hline
\end{tabular}

Table 3. Sample size (n), mean, standard error (SE), and range of average and greatest daily movements (m) of male San Joaquin antelope squirrel (Ammospermophilus nelsoni) by age class (adult, sub-adult, and juvenile) and by treatment (grazed) and control (ungrazed) plots in 2002 based on radio locations at the Lokern study site in the southern San Joaquin Desert of California, USA.

\begin{tabular}{|c|c|c|c|c|c|c|c|c|}
\hline \multirow{2}{*}{$\begin{array}{l}\text { Age Class/ } \\
\text { Plot Type }\end{array}$} & \multicolumn{4}{|c|}{ Average } & \multicolumn{4}{|c|}{ Greatest } \\
\hline & $\mathrm{n}$ & Mean & $\mathrm{SE}$ & Range & $\mathrm{n}$ & Mean & SE & Range \\
\hline Adults & 11 & 118.2 & 9.73 & $71.4-135.8$ & 11 & 286.3 & 26.6 & $164.4-443.0$ \\
\hline Sub-adults & 5 & 141.1 & 23.6 & $85.4-222.1$ & 5 & 370.2 & 63.7 & $195.5-571.7$ \\
\hline Juveniles & 3 & 145.2 & 43.2 & $75.7-224.5$ & 3 & 340.0 & 117.9 & $182.4-570.8$ \\
\hline Treatment & 12 & 135.7 & 14.2 & $72.7-224.5$ & 12 & 353.4 & 38.8 & $164.4-571.7$ \\
\hline Control & 7 & 116.2 & 13.0 & $71.4-175.4$ & 7 & 243.9 & 24.2 & $138.0-324.8$ \\
\hline Combined & 19 & 128.5 & 10.2 & $71.4-224.5$ & 19 & 313.0 & 28.4 & $138.0-571.7$ \\
\hline
\end{tabular}

by squirrels on control plots was $116.2 \mathrm{~m}$ (Table 3 ) and these differences were not significant $\left(F_{1,17}=0.85, P=0.369\right)$, nor were the greatest distances moved daily $(353.4 \mathrm{~m})$ on treatment plots or on control plots $(243.9 \mathrm{~m})$ by squirrels $\left(F_{1,17}=4.02, P=0.061\right)$. The average distance moved daily irrespective of plot type was $128.5 \mathrm{~m}$ and the greatest mean distance moved daily was $313.0 \mathrm{~m}$. Average daily movements of squirrels based on movements between traps (Table 4$)$ did not differ significantly by $\operatorname{sex}\left(F_{1,169}=0.14, P=0.707\right)$ or plot type $\left(F_{1,169}=3.40, P=0.067\right)$, nor was there a significant interaction $\left(F_{1,169}=0.93, P=0.337\right)$.

We found that mean RDM on the control plots $\left(1189.7 \mathrm{~g} / \mathrm{m}^{2}\right)$ was almost 14 times higher than mean RDM on the treatment plots $\left(85.67 \mathrm{~g} / \mathrm{m}^{2}\right)$. The difference in RDM between plot type was significant $\left(F_{1,4}=57.91, P=0.002\right)$. We did not find a significant difference in mean daily invertebrate numbers between control (1.70) and treatment (1.17) plots $\left(F_{1,4}\right.$ $=2.17, P=0.215$ ). 
Table 4. Sample size (n), mean (m), $95 \%$ confidence interval (CI), and range of daily movement distances of male and female San Joaquin antelope squirrel (Ammospermophilus nelsoni) based on trapping in treatment (grazed) and control (ungrazed) plots in August 2002 at the Lokern study site in the southern San Joaquin Desert of California, USA. Movements are based on trap locations of squirrels on eight plots (four control and four treatment). Distances between traps were $40 \mathrm{~m}$.

\begin{tabular}{lllll}
\hline Plot Type/Sex & $\mathrm{n}$ & Mean & $95 \%$ CI & Range \\
\hline Control Males & 37 & 52.2 & 8.06 & $0-215$ \\
Control Females & 41 & 56.7 & 7.16 & $0-179$ \\
Treatment Males & 45 & 73.7 & 6.94 & $0-240$ \\
Treatment Females & 50 & 63.5 & 7.71 & $0-283$ \\
\hline
\end{tabular}

\section{DISCUSSION}

It is surprising to us that a species that has been of conservation concern for almost 40 $y$ has had so few studies of its ecology, such as reproduction, density, demographic structure, home range, and movements. Besides being useful for general comparisons of life histories across species in the genus, as well as comparisons among the Sciuridae, these ecological data are necessary for conservation and recovery of the species. Ammospermophilus nelsoni continues to face development and habitat loss within its range and agency personnel can use data such as home range and movements to better determine means to evaluate effects and mitigate impacts from these developments.

We found that the home range size of 19 male $A$. nelsoni on the Lokern varied greatly from 1.25-14.5 ha. We determined these home range sizes during August and September, a time when $A$. nelsoni are not reproductive (unpublished data). Home range sizes may differ in other seasons, especially when $A$. nelsoni are reproducing or when tending young. The overall mean home range size we found on the Lokern (5.93 ha) is higher than the $100 \%$ MCP estimates for male (3.73 ha) and female (2.29 ha) A. nelsoni made by Harris and Stearns (1991) on the Elkhorn Plain, but lower than estimates they made using a sample-size corrected MCP (males $=9.01$ ha, females $=6.03$ ha). We do not think that the sample-size corrected MCP estimates are a good comparison for our estimate. Although Harris and Stearns (1991) radio-tracked squirrels, of the three males for which they gave a home range estimate, one had a sample size of six locations. Of the five females, two had only seven and eight locations. They also gave estimates for seven juveniles, but all estimates were based on fewer than 15 locations. We recalculated $100 \%$ MCP estimates given by Harris and Stearns (1991, Table 8) for individuals with $\geq 15$ locations and found average male home range size was $4.91 \mathrm{ha}( \pm 2.88 \mathrm{SD}, \mathrm{n}=2)$ and for females was 3.15 ha $( \pm 1.41 \mathrm{SD}, \mathrm{n}=3)$. Our home range estimate of 5.93 ha was not significantly different than the recalculated male estimate of 4.91 ha (Wilcoxon Signed Rank test; $W=107.0, \mathrm{df}=1$, $P=0.644$ ) of Harris and Stearns.

The only other home range estimate for A. nelsoni is from Hawbecker (1958) but is based on trap locations. Although he gave several examples, his estimate of the home range of $A$. nelsoni was 4.45 ha (11 acres) based on one male captured over 1 year. This estimate also is not significantly different than our estimate of home range size $(W=120.0, P=0.324)$. We did not radio-tag females, but our data on between trap movements is of some value for 
what home ranges of females might be on our site. Although not a perfect analogue to home range, the lack of significant differences between the sexes in trap movement might mean that home range size is not different if we had followed females at our site.

There are two estimates of home range size for the congener white-tailed antelope squirrel (A. leucurus), but both are based on movements within a trapping grid. Using various methods to determine home range, Bradley (1967) estimated home range size as 3.24 ha, $6.03 \mathrm{ha}$, and $8.34 \mathrm{ha}$, but determined 6.03 ha to be the best estimate. Jorgensen and Hayward (1965) found home range sizes of males from 3.00 to 16.47 ha, but these are especially poor estimates because they are based on only 3.0 to 4.4 captures per male. Using radio-telemetry locations, Harris and Leitner (2004) found a home range size of 6.73 ha for 16 adult male Mohave Ground Squirrels (Xerospermophilus mohavensis) in the western Mojave Desert of California. Although in a different genus, S. mohavensis is similar in size to antelope squirrels with weights varying from 70-300 g (Kays and Wilson 2002).

We found that the home range estimates based on $100 \% \mathrm{MCP}$ on the Lokern Natural Area differed significantly between grazed and ungrazed plots, with squirrels using almost twice as large an area where cattle had grazed the site. Both plant material and arthropods make up a large portion of the diet of $A$. nelsoni (Hawbecker 1947; Harris 2019). During 2002, we found that RDM (an estimate of plant food available to A. nelsoni) was significantly greater on the control plots than treatment plots, while the number of invertebrates we found in pit-fall traps was similar. This may account for the smaller home ranges of squirrels in the control plots. Squirrels on the treatment plots may have had to forage much more widely to meet dietary needs in 2002. Although denser vegetation on control plots may mean squirrels do not have to forage as widely as in grazed plots, squirrels may be more susceptible to predators if dense vegetation conceals the presence of predators better than in the more open grazed areas. Interestingly, over the course of the 10-y study of the effects of grazing on various protected species on the Lokern, numbers of $A$. nelsoni were significantly greater on treatment plots than on the ungrazed controls (Germano et al. 2012). Numbers varied widely over the $10 \mathrm{y}$, but ultimately sustained, high herbaceous cover depresses numbers of A. nelsoni (Germano et al. 2001, 2012).

Home range size gives information about how large an area is used by a species over an extended time period but does not indicate if an animal travels short distances to move within its home range, or if long daily distances are traveled. This also can be important to understanding the energetics of species and to assess the risk of an animal traveling into a project site in a short time. We found that the average daily movements of male $A$. nelsoni was almost $130 \mathrm{~m}$, and the average greatest distance moved daily was $313 \mathrm{~m}$, with some movements $>0.5 \mathrm{~km}$ in a day. Harris and Stearns (1991) did not report movement distances and Hawbecker (1958) reported various movements, sometimes over days and sometimes over years, so data are not comparable to what we found. Based on trap grid data for other antelope squirrels, Chew and Chew (1970) reported that the average movement distances of Harris's antelope squirrels (A. harrisii) was $274 \mathrm{~m} /$ individual, and for A. leucurus, Allred and Beck (1963) reported the greatest distance between captures was up to $129.5 \mathrm{~m}$ for males and $127.1 \mathrm{~m}$ for females, and Bradley (1967) gave the mean greatest distance between captures as $343.5 \mathrm{~m}$. Although gathered in a different way than us, movement data among antelope squirrels appears to be similar.

Like other antelope squirrels, $A$. nelsoni is a highly social rodent that is very active during the day, and its recovery from threatened status will benefit greatly from additional and comprehensive ecological and natural history research. The few ecological studies that 
have been conducted to date focusing on $A$. nelsoni are lacking in rigor, ours included. Only ours and the non-peer reviewed study by Harris and Stearns (1991) have used radiotelemetry to determine home ranges of antelope squirrels. Because rodents travel off grids, only radio-telemetry can accurately capture the full home range of individuals during an active season. Our study suffered from not including females, which we believed necessary at the time to increase sample size. Also, we only followed individuals for about $45 \mathrm{~d}$. Our data are useful to further refine the estimates of home range and movements of this neglected protected species, but in the future, better home range studies would collect radio locations 3-4 times per week starting in the spring and following squirrels for 3-4 mo and at least for $2 \mathrm{y}$. We suggest repeating the studies on home range on the Elkhorn Plain and the Lokern using the guidelines above, and that additional studies should be carried out on the valley floor, perhaps at the Semitropic Ecological Reserve of the California Department of Fish and Wildlife, and at a site in the Panoche Valley. Multiple sites would give the full range of variation in home range and movements of $A$. nelsoni, which could guide recovery actions aimed at conserving sufficient habitat to sustain populations of the squirrel.

\section{ACKNOWLEDGMENTS}

We thank Justin Brown who gathered most of the GPS locations. We also thank Peter Cross (deceased) of the U.S. Fish and Wildlife Service, who helped us secure funding for this portion of our research at the Lokern study area. We are grateful to Scott Phillips for making Figure 1 and Tory Westall for Figure 2. The study was carried out under a California Department of Fish and Game Memorandum of Understanding and followed the guidelines for animal care from the Ad hoc Committee on Acceptable Field Methods in Mammalogy (1987).

\section{LITERATURE CITED}

Ad hoc Committee on Acceptable Field Methods in Mammalogy. 1987. Acceptable field methods in mammalogy: preliminary guidelines approved by the American Society of Mammalogists. Journal of Mammalogy 68(Supplement):1-18.

Allred, D. M., and D. E. Beck. 1963. Range of movement and dispersal of some rodents at the Nevada Atomic Test Site. Journal of Mammalogy 44:190-200.

Best, T. L., A. S. Titus, C. L. Lewis, and K. Caesar. 1990. Ammospermophilus nelsoni. Mammalian Species 367:1-7.

Bradley, W. G. 1967. Home range, activity patterns, and ecology of the antelope ground squirrel in southern Nevada. Southwestern Naturalist 12:231-251.

Chappell, M. A., and G. A. Bartholomew. 1981. Activity and thermoregulation of the antelope ground squirrel Ammospermophilus leucurus in winter and summer. Physiological Zoology 54:215-233.

Chew, R. M., and A. E. Chew. 1970. Energy relationships of the mammals of a desert shrub (Larrea tridentata) community. Ecological Monographs 40:1-21.

Cypher, B. L., C. D. Bjurlin, and J. L. Nelson. 2009. Effects of roads on endangered San Joaquin kit foxes. Journal of Wildlife Management 73:885-893.

Eisenberg, J. F. 1975. The behavior patterns of desert rodents. Pages 189-224 in I. Prakash, and P. K. Ghosh, editors. Rodents in Desert Environments. Springer Nature, London, UK. 
Germano, D. J., and G. B. Rathbun. 2016. Home range and habitat use by blunt-nosed leopard lizards in the southern San Joaquin Desert of California. Journal of Herpetology 50:429-434.

Germano, D. J., R. B. Rathbun, and L. R. Saslaw. 2001. Managing exotic grasses and conserving declining species. Wildlife Society Bulletin 29:551-559.

Germano, D. J., G. B. Rathbun, L. R. Saslaw, B. L. Cypher, E. A. Cypher, and L. Vredenburgh. 2011. The San Joaquin Desert of California: ecologically misunderstood and overlooked. Natural Areas Journal 31:138-147.

Germano, D. J., G. B. Rathbun, and L. R. Saslaw. 2012. Effects of grazing and invasive grasses on desert vertebrates in California. Journal of Wildlife Management 76:670-682.

Ghobrial, L. I., and T. A. Nour. 1975. The physiological adaptations of desert rodents. Pages 413-444 in I. Prakash, and P. K. Ghosh, editors. Rodents in Desert Environments. Springer Nature, London, UK.

Grinnell, J., and J. Dixon. 1918. Natural history of the ground squirrels of California. Monthly Bulletin, California State Commission of Horticulture 7:3-116.

Harris, J. H. 1998. Ammospermophilus nelsoni Nelson's antelope squirrel. Pages 33-35 in D. J. Hafner, E. Yensen, and G. L. Kirkland, Jr., compilers. North American Rodents. Status Survey and Conservation Action Plan. IUCN/SSC Rodent Specialist Group. International Union for Conservation of Nature, Gland, Switzerland.

Harris, J. H. 2019. Diet of the San Joaquin antelope squirrel in the southern portion of its range. Western Wildlife 6:23-28.

Harris, J. H., and P. Leitner. 2004. Home-range size and use of space by adult Mohave ground squirrels, Spermophilus mohavensis. Journal of Mammalogy 85:517-523.

Harris, J. H., and D. M. Stearns. 1991. Population density, census methods, habitat relationships, and home range of the San Joaquin antelope squirrel, 1988-89. Nongame Bird and Mammal Section Report 91-02. California Department of Fish and Game, Sacramento, CA, USA.

Hawbecker, A. C. 1947. Food and moisture requirements of the Nelson antelope ground squirrel. Journal of Mammalogy 28:115-125.

Hawbecker, A. C. 1958. Survival and home range in the Nelson antelope ground squirrel. Journal of Mammalogy 39:207-215.

Heller, H. C., and J. A. Henderson. 1976. Hypothalamic thermosensitivity and regulation of heat storage behavior in a day-active desert rodent Ammospermophilus nelsoni. Journal Comparative Physiology 108:255-270.

Jorgensen, C. D., and C. L. Hayward. 1965. Mammals of the Nevada Test Site. Brigham Young University Science Bulletin, Biological Series 6:1-81.

Kays, R. W., and D. E. Wilson. 2002. Mammals of North America. Princeton University Press, Princeton, NJ, USA.

Mantooth, S. J., D. J. Hafner, R. W. Bryson, and B. R. Riddle. 2013. Phylogeographic diversification of antelope squirrels (Ammospermophilus) across North American deserts. Biological Journal of the Linnean Society 109:949-967.

Mason, M. J. 2016. Structure and function of the middle ear. I: Large middle ears in small desert mammals. Journal of Anatomy 228:284-299.

U.S. Fish and Wildlife Service (USFWS). 1998. Recovery plan for upland species of the San Joaquin Valley, California. United States Fish and Wildlife Service, Portland, OR, USA. 
Walsberg, G. E. 2000. Small mammals in hot deserts: some generalizations revisited. Bioscience 50:109-122.

Submitted 7 October 2019

Accepted 2 December 2019

Associate Editor was $S$. Osborne 